Work in progress on the fractionation of polymers and on the preparation and properties of ion-exchange membranes was shown in the High Polymers Group. The mechanical and physical properties of many industrially important polymers are dependent on molecular weight ; two promising new techniques for determining molecular weight distributions were exhibited. One method consists of fractionating polymers in solution by causing the heterodisperse polymer to diffuse across membranes of varied selectivity. Advantages of this procedure are that the polymer is in true solution throughout the fractionation, and relatively large amounts of material can be treated in apparatus which is much more compact than that used in techniques employing fractional precipitation or dissolution. The other method, primarily of value for low-molecular weight polymers, is a development of the technique of paperstrip chromatography to provide a rapid semi-micro procedure for determining molecular-weight distributions.

Much interest is now being shown in the possible large-scale application of multicompartment electrodialysis eells to the demineralization of brackish water, and to treatment of industrial effluents. 'The efficient operation of such cells is markedly dependent on the properties of the ion-exchange membranes used, and extensive studies of the preparation and properties of ion-exchange films are in progress at the Laboratory. One exhibit showed the results of a systematic study of membranes prepared by incorporating finely divided ion-exchange resins of different degrees of cross-linkage into an inert polymeric binder.

\title{
POMOLOGICAL RESEARCH IN POLAND
}

\author{
By L. C. LUCKWILL \\ Long Ashton Research Station, University of Bristol
}

$\mathrm{O}$ N May 23 the new buildings of the Polish Research Institute of Pomology at Skierniewice, about forty miles south-west of Warsaw, were officially opened by the Polish Vice-Minister of Agriculture, Mr. Szajer. This event, which marks the beginning of a new era of pomological research in Eastern Europe, was the occasion for a conference attended by Polish research workers and by twenty-four foreign delegates representing thirteen different European countries.
The Research Institute of Pomology was founded in 1951 as part of the post-war plan to co-ordinate pomological research in Poland, which previously had been conducted at many different centres controlled either by the State Agriculture Institute at Putawy or by the agricultural colleges at Warsaw, Lublin, Poznan, Krakow and Wroctaw. The Institute is housed in a large three-storied building which, in addition to modern laboratory and library facilities, contains a large conference room, canteen and com-

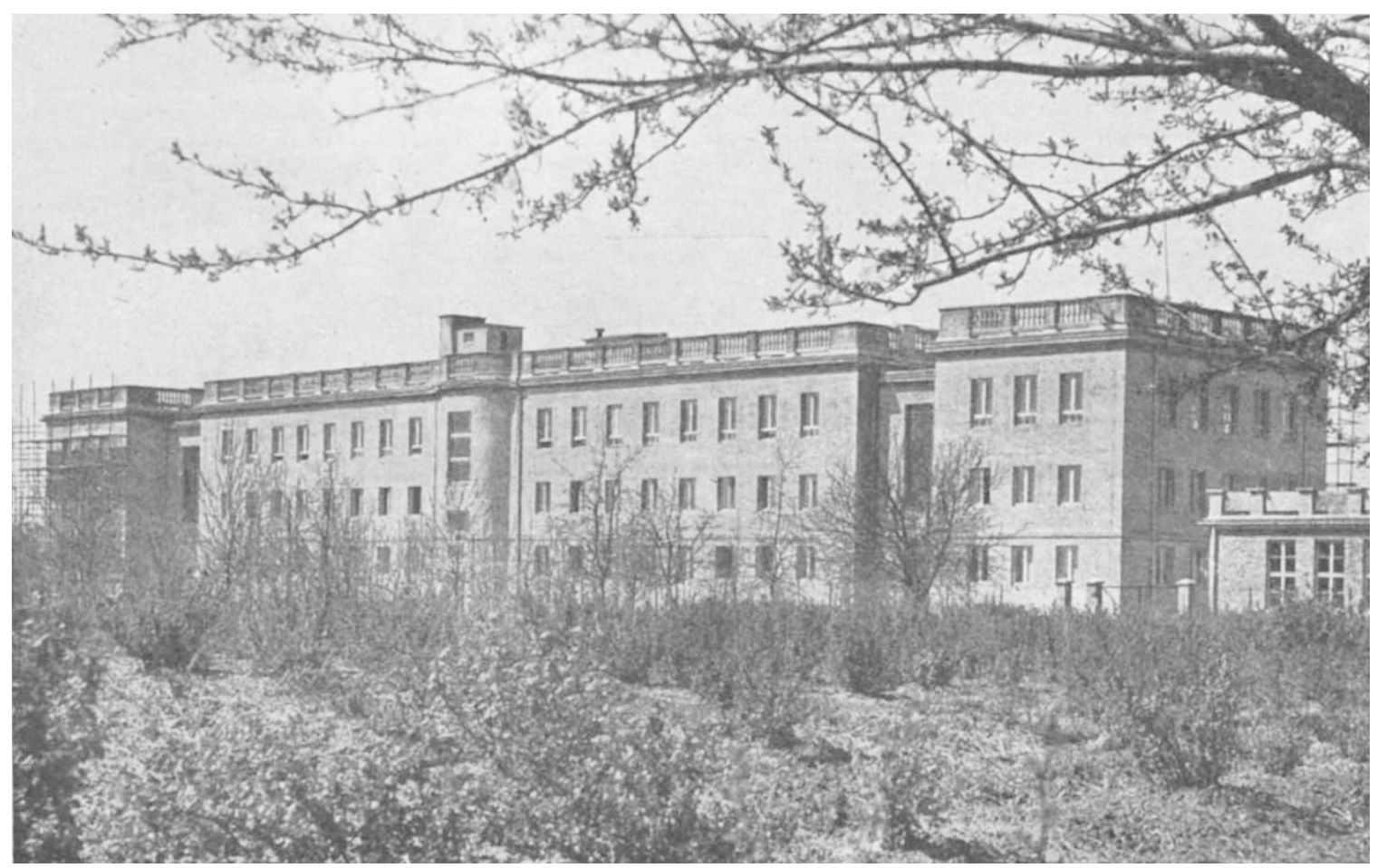

Fig. 1. Institute of Pomology, Skierniewice, Poland 
mon rooms for the staff, living accommodation for visiting workers and a permanent exhibition room containing demonstrations for visiting fruit-growers. Adjacent to the Institute are a number of apartment houses for the staff, and future plans envisage the addition of an extensive block of experimental glass-houses and cold stores. On one side of the building lies the large experimental orchard of the Warsaw College of Agriculture containing demonstration experiments and an important collection of 1,800 species and varieties of cultivated fruits.

Most of the field experiments of the Institute are carried out at field stations situated in the different fruit-growing regions of the country. In all there are eleven such field stations, varying in size from 140 to 1,440 acres, each under the control of a director and small scientific staff, working in close co-operation with the staff of the Institute. The total area available for such field experiments is about 5,800 acres, of which a considerable proportion is at present devoted to extensive variety trials of tree fruits, currants, gooseberries and strawberries. The chief object of these trials is to find high-yielding varieties of good quality that are capable of surviving the extreme cold of the Polish winter. The trials themselves are well laid out and are randomized and replicated to an extent sufficient to satisfy the most fastidious statistician. In addition to these field stations the Institute has also planted many experimental and demonstration orchards on the State farms, and a few on peasants' holdings.

The creation of the Research Institute is due largely to the enterprise and initiative of the present director, Prof. S. A. Pieniażek, who returned to Poland from the United States in 1946. One of his chief difficulties throughout has been the acute shortage of trained scientific workers. At the end of the Second World War there were only four persons with Ph.D. degrees working in pomology in Poland : to-day the number has risen to about twenty, but most of the ninety-nine members of the scientific staff of the Institute are recent graduates with relatively liutle research experience. A few have received training in Moscow, and almost all have the ambition to work for a time in
England in order to broaden their experience or to acquire specialist techniques.

The work of the Research Institute is divided into twelve departments designed to cover most of the problems of importance for fruit growing, such as soil cultivation, fruit breeding, mechanization, plant protection, and fruit technology. Winter killing is undoubtedly the most serious problem confronting fruit growers in Poland, and much research effort is devoted to the study of this problem, particularly to methods of increasing winter hardiness of trees and the selection of cold-resistant varieties. The importance of this problem is shown by the violent fluctuations of the fruit tree population during recent years. It is estimated that in 1939 there were about fifty million fruit trees in Poland. More than half of these were destroyed by cold in the winter of 1939-40, and by the end of the War the population had further decreased to twenty-two million. Extensive post-war plantings, which are still continuing, had raised the number to approximately thirty-five million in 1955 ; but a further severe winter during 1955-56 again wrought great havoc, particularly among pears and plums, in the orchards of central Poland.

In the Soviet Union, pornological science, under the influence of Michurin, has developed along lines different from those pursued in Western Europe and Scandinavia, and many concepts basic to Russian pomological work (for example, graft hybridization; the 'mentor' theory) are regarded with scepticism by pomologists in other countries, including, incidentally, many in Poland. Soviet pomologists, on the other hand, are equally sceptical of much Western work, particularly that relating to virus diseases in fruit crops and the application of statistical methods to field experiments. Poland, open to cultural influences from both East and West, is bound to neither school of thought, and the present policy of pomological research is to make use of those ideas and techniques that seem most appropriate to the problems in hand, irrespective of their origins. Here, indeed, in a limited field of endeavour, we have a true hybrid between Eastern and Western scientific thought which, though yet young, already manifests the marked vigour characteristic of crosses between widely dissimilar parents.

\section{DISLOCATIONS AND THE MECHANICAL PROPERTIES OF CRYSTALS}

$\mathrm{D}$ URING September 6-8, about forty metallurgists and physicists from various countries met at Lake Placid, New York, to discuss the mechanical properties of dislocated crystals. The conference was sponsored jointly by the U.S. Office of Scientific Research, Air Research and Development Command and by the General Flectric Research Laboratory, Schenectady, and organized by Dr. J. C. Fisher. The discussions were quite informal and their purpose was to assess, in the light of recent work, the extent to which we understand the mechanical effects of dislocations in crystals. A few related questions were also taken up, such as the growth of whisker crystals and the nature of radiation damage.

Comparing this conference with those held in the United Kingdom in 1954, I was struck by two major changes in the subject, both of which were foreseen at the earlier conferences. First, the study of dislocations has now become very definitely an experimental- ist's subject. By contrast, the development of dislocation theory has, temporarily at least, almost ceased. The reason for this is fairly clear. The geometrical and elastic theories of single dislocations and of simple arrays of dislocations have now been almost completely worked out, and only the very hard problems of the dynamics of fast-moving dislocations and of the detailed atomic structures in the cores of dislocations remain. But to understand workhardening, creep, fatigue, fracture and recrystallization, we have to study the collective behaviour of large, complex assemblies of dislocations, and the theory of this can go forward only when experiments have shown what are the decisive aspects of this behaviour in practice.

The second striking change is that the experimentalists are no longer content to look merely at slip lines. Stimulated mainly by the development of etch-pit techniques and by methods of precipitating 